\title{
Fake news, trolls y otros encantos. Cómo funcionan (para bien y para mal) las redes sociales
}

\author{
Ernesto Calvo y Natalia Aruguete (Autores) \\ Buenos Aires: Siglo XXI Editores. 2020. 228 páginas.
}

\section{Natalia Zuazo}

https://doi.org/10.46468/rsaap.14.2.R1

Todavía hoy, a más de 50 años del nacimiento de internet y 15 de que convivimos con redes sociales, la expresión "nuevas tecnologías" tiene lugar en algunas conversaciones. Todavía hoy, cuando el análisis de las redes sociales existe desde hace sesenta años (aunque como descripción de relaciones entre personas de carne y hueso), en muchas ocasiones buscamos descubrir la total novedad de estas nuevas interconexiones mediadas por fibra óptica. Todavía hoy, la voluntad por describir fenómenos absolutamente nuevos nos deslumbra. Es allí donde Fake news, trolls y otros encantos, el libro de Ernesto Calvo y Natalia Aruguete, viene a hacer lo que hacen las ciencias sociales: separar lo nuevo y lo viejo, iluminar el mapa con los elementos de la comunicación, la ciencia política y la estadística que ya existían desde antes, y con los que se están sumando en los últimos años. Con teoría y con práctica, el libro nos ayuda a no perdernos en un camino que no empezó recién en muchos sentidos, pero que en otros necesita todavía construirse.

Para quienes trabajamos en el cruce entre política y tecnologías, 2016 fue un año de cambios. Con la campaña por la presidencia de Estados Unidos de Donald Trump en marcha y el referéndum por la salida del Reino Unido de la Unión Europea triunfante, las redes sociales se posicionaron por primera vez como la principal vía de acceso de las personas a la información política. Las campañas electorales, ya desde antes de la elección de Barack Obama pero especialmente luego de su triunfo, encontraron en las redes sociales un espacio de crecimiento. Con más tiempo en las redes para consumir noticias y opinar de política, la interacción con otros también fue creciendo. Pero pronto nos dimos cuenta de que ninguno de nosotros llegaba a esos espacios virtuales carente de prejuicios y creencias previas, y que ni siquiera las intenciones comunicativas eran compartidas. Aún más: si alguien en 2016 todavía creía que internet era un espacio horizontal y democrático, una mezcla de fuerzas afectivas y algorítmicas de las redes terminaron por derribar el mito.

Calvo (politólogo, doctor por la Universidad Northwestern, profesor de Gobierno y Política de la Universidad de Maryland) y Aruguete (comunicadora, investigadora del Conicet y profesora de la Universidad Nacional de Quilmes y de la Universidad Austral) explican esta historia apasionante y todavía poco tratada en la bibliografía específica en español en un libro dividido en tres partes: Usuarios, Encuadres y Redes. En la primera se centran en nosotros, las personas, y en cómo nos movemos en las redes por una combinación de reacciones cognitivas, afectivas y políticas. Allí indagan sobre las razones profundas, la construcción de las noticias falsas, pero sobre todo, la posibilidad de su creencia y de su 
propagación por parte de las personas. "Cuando no hay consenso, las news se convierten en fake news”, señalan los autores, para luego introducir una lectura detallada que involucra lecturas recientes sobre la polarización política en distintas sociedades. Como complemento, experimentos de big data en redes sociales para conocer los efectos de los \#Tarifazos en 2016 y la desaparición de Santiago Maldonado en 2017 agregan elementos de análisis.

En la segunda parte, el libro posa su foco en los encuadres: se pregunta qué luces encendemos y qué otras apagamos esos usuarios que llegamos a las redes con prejuicios, afectos, formando comunidades. Lo sepamos o no en nuestra baldosa de las redes, "cada decisión cambia la frecuencia de las imágenes, de las palabras, de los hashtags y de los vínculos en la red", señalan los autores. Esas decisiones que tomamos desencadenan un proceso fundamental que se describe durante todo el libro, la "activación en cascada". A partir de ese proceso es que las redes pueden leerse: adquieren estructura, intención y sentido. Es decir, se vuelven un objeto de la ciencia que empieza a hablar. Con esos conceptos y los datos sobre la mesa, Calvo y Aruguete llegan a frases como esta: "Las burbujas no son solo un espejo, sino que devuelven una versión aumentada de nuestras propias creencias". Estamos en las redes, creemos que nos informamos racionalmente, pero si miramos de lejos la estructura, tal vez estemos sobrerrepresentando nuestra opinión.

En la tercera parte, los autores llevan el análisis a dos situaciones opuestas: una (el caso Bolsonaro), donde una red puede crearse de manera completamente ficticia para apoyar una historia; la otra (el caso \#AbortoLegal), donde una red puede crecer "desde abajo" sin ayuda de medios tradicionales ni cuentas con mu- chos seguidores y sin embargo adquirir una potencia capaz de traspasar a esos mismos medios con el tiempo. Además del interés que conlleva leer ambas construcciones tecno-político-mediáticas, esta parte del libro tiene una virtud extra: nos muestra que en el estudio profesional de las redes sociales cada caso es particular y, por lo tanto, requiere un análisis de escenario y datos propios. En algunos medios de comunicación masivos, todavía de la misma manera que se caracteriza cualquier operación en redes como "ataque troll”, sin más detalle, puede caracterizarse la emergencia de una figura como Jair Bolsonaro como un "outsider político", sin más detalle. Calvo y Aruguete se toman el tiempo para caracterizar el origen, el alcance y la activación de las redes de Bolsonaro con precisión, al tiempo que precisan su advenimiento en el escenario electoral, y así componen un panorama con más grises, pero con más precisiones.

“¿Por qué abandonamos la promesa de una comunicación irrestricta, horizontal y democrática para ingresar en este páramo de distopías congnitivas, operaciones políticas y distorsiones comunicacionales?", se preguntan los autores al iniciar el libro, en su primera página. En las 228 restantes dan elementos para comprender cómo llegamos a ese escenario. Hacia el final, suman el problema estructural, el de la concentración de una gran cantidad de datos en pocas manos: el de un pequeño grupo de dueños de internet que los monetizan o gobiernos que los explotan. "El abandono de las redes sociales a los actores con más recursos explica en gran medida las formas sociales de la violencia digital que sufrimos hoy en día”, escriben. Y, a continuación, ofrecen una posibilidad de avanzar hacia algo mejor: "Es también posible, sin embargo, utilizar estas herramientas para reclamar 
Reseñas

la responsabilidad política de los usuarios que promueven formas organizadas de violencia".

Fake news, trolls y otros encantos, con su capacidad de hacer más legible un mundo que ya no es nuevo (el de las redes, el del cruce de la política y la tecnología), pero que sí tiene novedades que debemos estudiar, caracterizar y profundizar, viene a ayudarnos en esa tarea. Si pudiéramos pensar en el horizonte de un mundo con un "big data para todos", o al menos uno donde la información fuera más transparente para más personas, este libro debería ser parte de la educación inicial. Para empezar, su lectura, con seguridad, nos ayudará a construir herramientas para tener mejores mapas para comenzar ese recorrido. 